\title{
Local daily temperatures, thermal seasons, and suicide rates in Finland from 1974 to 2010
}

\author{
Laura Hiltunen $\cdot$ Jari Haukka $\cdot$ Reija Ruuhela $\cdot$ \\ Kirsi Suominen · Timo Partonen
}

Received: 15 October 2013/Accepted: 31 March 2014/Published online: 3 May 2014

(C) The Japanese Society for Hygiene 2014

\begin{abstract}
Objectives Suicide peaks in late spring and October are still seen in Finland among many countries. Weather factors have been suggested as explanations for these peaks, although with inconsistent results. Since the exact timing of these peaks varies each year, the length of daylight and changes in it seem inadequate as an explanation. We hypothesized that ambient temperature and the timing of thermal seasons might associate with suicide rate.

Methods Suicide rates from three areas across Finland $(N=10,802)$ were analyzed with Poisson regression in six different models against variables calculated from the local ambient daily temperature, diurnal temperature range, and
\end{abstract}

Electronic supplementary material The online version of this article (doi:10.1007/s12199-014-0391-9) contains supplementary material, which is available to authorized users.

L. Hiltunen $(\varangle) \cdot$ J. Haukka $\cdot$ K. Suominen $\cdot$ T. Partonen

Department of Mental Health and Substance Abuse Services, National Institute for Health and Welfare, Mannerheimintie 166, P.O. Box 30, 00271 Helsinki, Finland

e-mail: laura.hiltunen@thl.fi

L. Hiltunen

Department of Psychiatry, Helsinki University Central Hospital, Jorvi Hospital, Espoo, Finland

\section{J. Haukka}

Department of Public Health, University of Helsinki, Hjelt Institute, Helsinki, Finland

R. Ruuhela

Finnish Meteorological Institute, Helsinki, Finland

K. Suominen

Department of Social Services and Health Care, Psychiatry, Helsinki, Finland the duration from the onset of thermal seasons. Separate models for men and women were constructed.

Results The temperature change over 5 days associated with the suicide rate of men in Helsinki region, or in other words, the lower the suicide rate was, the higher the temperature decrease had been. For women, the results were more inconsistent.

Conclusions Our study is in line with some earlier studies which imply that impairment of thermoregulation might exist among suicide victims.

Keywords Ambient · Local · Meteorological · Regional · Risk - Weather

\section{Introduction}

In our earlier nationwide study from Finland, suicide rate correlated with monthly mean temperature along with global radiation [1], and in another Finnish study, the ambient temperature variation was shown to explain even $60 \%$ of the annual suicide variance in extra-long time series from 1751 to 2008 in Finland [2]. Furthermore, the diurnal temperature variation associated with spring peak of suicides in Helsinki metropolitan area [3]. However, contradictive data on the associations between suicide and ambient temperature exist as well $[4,5]$, and recent studies found inverse associations between annual ambient temperature and suicide rate [6,7], and a study concerning monthly mean temperature and suicide rate, no association whatsoever [8]. Moreover, the analysis of long series of monthly data on suicide and weather in Switzerland concluded that the association between temperature and suicide is not due to warm temperatures but due to the lack of low temperatures, or in other words, it is not heat but the 
lack of cold that contributes to this association [9]. However, the comparison of the results between different studies may be problematic since ambient temperature has been analyzed by using different lengths, mostly from 1 month to 1 year. Furthermore, differences between local climates may influence acclimatization, i.e., the physiological as well as psychological adjustment of individuals into local climate changes, and thereby may explain the conflicting results to some extent [10].

Seasonal peaks in suicide rates exist in Finland among many other countries [11-18]. A smaller peak in suicide rate is seen in October, especially for women [19-21], and the highest mean in the daily suicide rate emerges between May 15 and July 25 in Finland [22]. However, from year to year, the timings of these two peaks seem to vary. The early summer peak fluctuates between April and August, and the autumn peak between August and December.

Therefore, since the change of astronomical seasons, that is the length of day relative to night, follows a regular timetable year after year, we hypothesized that thermal seasons with a varying timetable each year influence the timings of the peaks in suicide rate. We aimed to study whether the daily variability in ambient temperature and thermal seasons associated with suicide rates in three areas and their local climates in Finland during a 37-year-long period.

\section{Materials and methods}

For the years of 1974-2010 inclusive, Statistics Finland (http://www.stat.fi/index_en.html) provided the daily numbers of suicides and the yearly populations according to the location (the longitude and the latitude of a community) in Finland for men and women in separate from three areas: (1) Helsinki (60N, 24E), the capital of Finland, in the southern coast of Finland, (2) Jyväskylä (62N, 25E), $270 \mathrm{~km}$ north of Helsinki, and (3) Oulu (65N, 25E), $338 \mathrm{~km}$ north of Jyväskylä. The suicides committed in these cities and the communities surrounding them within a

Table 1 Suicides from 1974 to 2010 by sex and study area

\begin{tabular}{llcll}
\hline Sex & Study area & \multicolumn{3}{l}{ Suicides } \\
\cline { 3 - 5 } & & $\begin{array}{l}\text { Absolute } \\
\text { number }\end{array}$ & $\begin{array}{l}\text { Rate per } \\
100,000\end{array}$ & $\begin{array}{l}95 \% \text { CI } \\
\text { for the rate }\end{array}$ \\
\hline \multirow{2}{*}{ Men } & Oulu $_{65 \mathrm{~N}, 25 \mathrm{E}}$ & 1088 & 36.8 & $34.7-39.1$ \\
& Jyväskylä $_{62 \mathrm{~N}, 25 \mathrm{E}}$ & 807 & 33.7 & $31.4-36.1$ \\
& Helsinki $_{60 \mathrm{~N}, 24 \mathrm{~N}}$ & 5756 & 37.6 & $36.6-38.6$ \\
\multirow{4}{*}{ Women } & Oulu $_{65 \mathrm{~N}, 25 \mathrm{E}}$ & 335 & 10.9 & $9.7-12.1$ \\
& Jyväskylä62N, 25E & 299 & 11.7 & $10.4-13.1$ \\
& Helsinki $_{60 \mathrm{~N}, 24 \mathrm{E}}$ & 2517 & 14.4 & $13.9-15.0$ \\
\hline
\end{tabular}

$25-\mathrm{km}$ radius were selected as the study group, and the absolute suicide number $(N=10,802)$ and suicide rates per 100,000 person-years (with $95 \%$ CI for the suicide rates) for each area, for men and women in separate, are presented in Table 1.

The local daily mean, minimum, and maximum temperatures from the local weather stations at the HelsinkiVantaa, Jyväskylä, and Oulu airports, and the dates for the thermal seasons for each study area for each year (for the definition, see: http://en.ilmatieteenlaitos.fi/seasons-in-fin land) and the dates for the astronomical seasons (for the definition of astronomical seasons, see: http://aa.usno.navy. mil/data/docs/EarthSeasons.php) were provided by the Finnish Meteorological Institute (www.fmi.fi). The lengths of thermal seasons (minimum, maximum, and mean number of days) in the three study areas are presented in Table 2. Monthly suicide rates (suicides per 100,000) for the three study areas, together with the local temperatures, from 1974 to 2010, for men and women in separate, are presented in Figs. 1 and 2.

For the statistical models, altogether 21 explanatory variables were formulated. They were named and numbered as follows: (1) the daily mean temperature $T$ (day 0 ) at the day of completed suicides, (2) change in the daily mean temperature from the previous day, $\Delta T_{1}=$ $T($ day0) $-T$ (day-1), (3) change in the daily mean temperature compared to the daily mean temperature 2 days before, $\Delta T_{2}=T($ day 0$)-T($ day-2), (4) change in the daily mean temperature compared to the daily mean temperature 3 days before, $\Delta T_{3}=T($ day0 $)-T($ day -3$)$, (5) change in the daily mean temperature compared to the daily mean temperature 4 days before, $\Delta T_{4}=T($ day 0$)-T$ (day-4), (6) change in the daily mean temperature compared to the

Table 2 Minimum, mean, and maximum lengths of thermal seasons from 1974 to 2010 by study area

\begin{tabular}{|c|c|c|c|c|}
\hline \multirow[t]{2}{*}{ Thermal season } & \multirow[t]{2}{*}{ Study area } & \multicolumn{3}{|c|}{ Number of days } \\
\hline & & Min & Mean & $\operatorname{Max}$ \\
\hline \multirow[t]{3}{*}{ Winter $T<0{ }^{\circ} \mathrm{C}$} & Oulu $_{65 \mathrm{~N}, 25 \mathrm{E}}$ & 110 & 160 & 192 \\
\hline & Jyväskylä $_{62 \mathrm{~N}}, 25 \mathrm{E}$ & 109 & 149 & 199 \\
\hline & Helsinki $_{60 \mathrm{~N}, 24 \mathrm{E}}$ & 53 & 126 & 176 \\
\hline \multirow[t]{3}{*}{ Spring $T=0^{\circ}-10^{\circ} \mathrm{C}$} & Oulu $_{65 N}, 25 \mathrm{E}$ & 8 & 46 & 77 \\
\hline & Jyväskylä $_{62 \mathrm{~N}}, 25 \mathrm{E}$ & 8 & 46 & 89 \\
\hline & Helsinki $_{60 N}, 24 \mathrm{E}$ & 12 & 47 & 90 \\
\hline \multirow[t]{3}{*}{ Summer $T>10^{\circ} \mathrm{C}$} & Oulu $_{65 N}, 25 \mathrm{E}$ & 72 & 105 & 141 \\
\hline & Jyväskylä $_{62 \mathrm{~N}}, 25 \mathrm{E}$ & 73 & 107 & 137 \\
\hline & Helsinki $_{60 \mathrm{~N}}, 24 \mathrm{E}$ & 91 & 131 & 164 \\
\hline \multirow[t]{3}{*}{ Autumn $T=10^{\circ}-0{ }^{\circ} \mathrm{C}$} & Oulu $_{65 \mathrm{~N}}, 25 \mathrm{E}$ & 12 & 58 & 102 \\
\hline & Jyväskylä $62 \mathrm{~N}, 25 \mathrm{E}$ & 21 & 64 & 104 \\
\hline & Helsinki $_{60 \mathrm{~N}, 24 \mathrm{E}}$ & 21 & 61 & 148 \\
\hline
\end{tabular}

$T$ daily mean temperature, $C$ degrees in Celsius 
Fig. 1 Men's monthly suicide rate suicides per 100,000 (black line), and smoothed (1 year window) temperature (gray line) in Oulu, Helsinki (Hki), and Jyväskylä (JKL) from 1974 to 2010. The right side vertical axis is for temperature $\left({ }^{\circ} \mathrm{C}\right)$

Fig. 2 Women's monthly suicide rate suicides per 100,000 (black line), and smoothed (1 year window) temperature (gray line) in Oulu, Helsinki (Hki), and Jyväskylä (JKL) from 1974 to 2010 . The right side vertical axis is for temperature $\left({ }^{\circ} \mathrm{C}\right)$
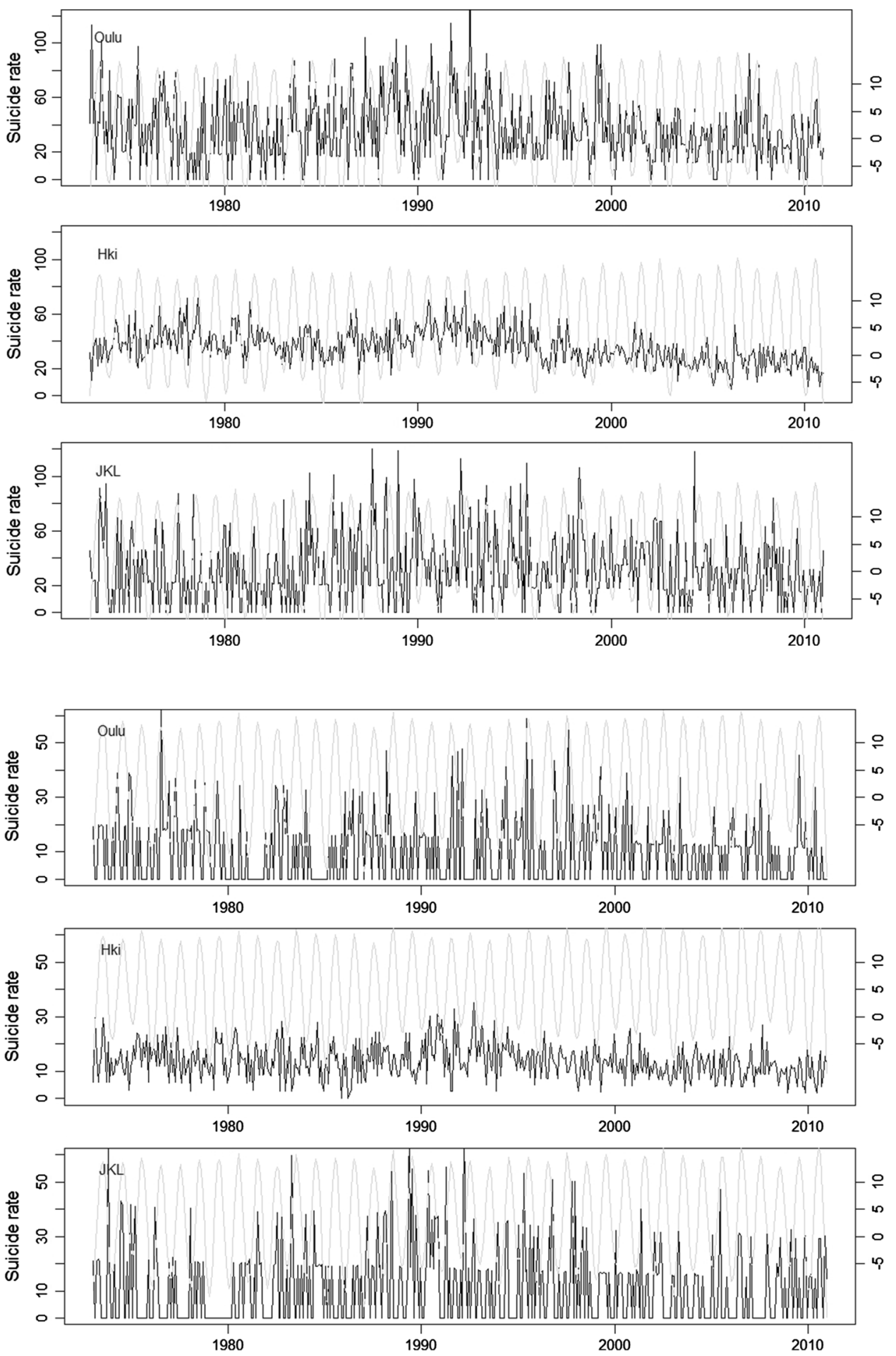

daily mean temperature 5 days before, $\Delta T_{5}=T($ day 0$)-$ $T$ (day-5), (7) the diurnal temperature change at the day of completed suicides $\Delta T_{\mathrm{d}}=T_{\max }$ (day 0$)-T_{\min }$ (day 0), (8) thermal seasons as categorical variables, (9) the number of days from the onset of thermal spring, (10) the number of days from the onset of thermal summer, (11) the number of days from the onset of thermal autumn, (12) the number of days from the onset of thermal winter, (13) astronomical seasons as categorical variables, (14) the number of days from the onset of astronomical spring, (15) the number of days from the onset of astronomical summer, (16) the number of days from the onset of astronomical autumn, (17) the number of days from the onset of astronomical winter, (18) the number of days during which astronomical 
Table 3 Explanatory variables by statistical model

\begin{tabular}{|c|c|c|c|c|c|c|c|}
\hline \multicolumn{2}{|c|}{ Explanatory variable } & \multicolumn{6}{|c|}{ Statistical model } \\
\hline & & & \multirow{2}{*}{$\frac{2}{*}$} & \multirow[t]{2}{*}{3} & \multirow{2}{*}{$\frac{4}{*}$} & \multirow{2}{*}{$\frac{5_{\mathrm{ss}}}{*}$} & \multirow{2}{*}{$\frac{6_{\mathrm{au}}}{*}$} \\
\hline 1 & $T($ day 0$)$ & & & & & & \\
\hline 2 & $\Delta T_{1}=T($ day 0$)-T($ day -1$)$ & * & $*$ & & * & $*$ & $*$ \\
\hline 3 & $\Delta T_{2}=T($ day 0$)-T($ day -2$)$ & $*$ & $*$ & & $*$ & $*$ & $*$ \\
\hline 4 & $\Delta T_{3}=T($ day 0$)-T($ day -3$)$ & * & $*$ & & $*$ & $*$ & $*$ \\
\hline 5 & $\Delta T_{4}=T($ day 0$)-T($ day -4$)$ & * & $*$ & & $*$ & $*$ & $*$ \\
\hline 6 & $\Delta T_{5}=T($ day 0$)-T($ day -5$)$ & * & $*$ & & $*$ & $*$ & $*$ \\
\hline 7 & $\Delta T_{d}=T_{\max }($ day 0$)-T_{\min }($ day 0$)$ & * & $*$ & & $*$ & $*$ & $*$ \\
\hline 8 & $\begin{array}{l}\text { Thermal seasons (spring, summer, } \\
\text { autumn, winter) }\end{array}$ & * & * & & & & \\
\hline 9 & $\begin{array}{l}\text { Number of days (from the onset of } \\
\text { thermal spring) }\end{array}$ & $*$ & $*$ & $*$ & & & \\
\hline 10 & $\begin{array}{l}\text { Number of days (from the onset of } \\
\text { thermal summer) }\end{array}$ & * & $*$ & $*$ & & & \\
\hline 11 & $\begin{array}{l}\text { Number of days (from the onset of } \\
\text { thermal autumn) }\end{array}$ & * & $*$ & $*$ & & & \\
\hline 12 & $\begin{array}{l}\text { Number of days (from the onset of } \\
\text { thermal winter) }\end{array}$ & $*$ & $*$ & $*$ & & & \\
\hline 13 & $\begin{array}{l}\text { Astronomical seasons (spring, } \\
\text { summer, autumn, winter) }\end{array}$ & * & & & & & \\
\hline 14 & $\begin{array}{l}\text { Number of days (from the onset of } \\
\text { astronomical spring) }\end{array}$ & $*$ & & & & & \\
\hline 15 & $\begin{array}{l}\text { Number of days (from the onset of } \\
\text { astronomical summer) }\end{array}$ & $*$ & & & & & \\
\hline 16 & $\begin{array}{l}\text { Number of days (from the onset of } \\
\text { astronomical autumn) }\end{array}$ & $*$ & & & & & \\
\hline 17 & $\begin{array}{l}\text { Number of days (from the onset of } \\
\text { astronomical winter) }\end{array}$ & * & & & & & \\
\hline 18 & $\begin{array}{l}\text { Mismatch days of astronomical and } \\
\text { thermal seasons }\end{array}$ & * & & & & & \\
\hline 19 & Weekday & $*$ & $*$ & & & $*$ & $*$ \\
\hline 20 & $\begin{array}{l}\text { Number of days (from the onset of } \\
\text { calendar year) }\end{array}$ & $*$ & $*$ & & & & \\
\hline 21 & Calendar year & $*$ & $*$ & * & $*$ & $*$ & $*$ \\
\hline
\end{tabular}

Variables in italics (\#7, \#8, \#13, \#18, \#19) were analyzed as categorical variables, whereas the natural spline method was applied for the rest

* The use of the variable in the model

$T$ mean daily temperature, $T($ Day 0$)$ daily mean temperature on the day of completed suicides, $T($ Day-1) daily mean temperature on the previous day of completed suicides, $T($ Day-2) daily mean temperature 2 days before the completed suicides, $T($ Day-3) daily mean temperature 3 days before the completed suicides, T(Day-4) daily mean temperature 4 days before the completed suicides, $T($ Day-5) daily mean temperature 5 days before the completed suicides, $\Delta T$ change in daily mean temperature; ss dates during the astronomic spring and summer (21 March-21 September) were analyzed in the model; aw dates during the astronomic autumn and winter (22 September-20 March) were analyzed in the model

and thermal seasons do not overlap, (19) weekday, (20) the number of days from the onset of each calendar year, and (21) the calendar year from 1974 to 2010 inclusive.
Table 4 Minimum, mean, and maximum daily mean temperatures from 1974 to 2010 by the astronomic periods (used in the statistical models \#5 and \#6) and study area

\begin{tabular}{|c|c|c|c|c|}
\hline \multirow[t]{2}{*}{ Astronomic period } & \multirow[t]{2}{*}{ Study area } & \multicolumn{3}{|c|}{ Temperature $\left({ }^{\circ} \mathrm{C}\right)$} \\
\hline & & Min & Mean & Max \\
\hline \multirow{3}{*}{$\begin{array}{l}\text { Astronomical spring and } \\
\text { summer } 21 \text { Mar-21 Sep } \\
\text { (model \#5) }\end{array}$} & Oulu $_{65 \mathrm{~N}}, 25 \mathrm{E}$ & -15.8 & 9.6 & 26.6 \\
\hline & Jyväskylä $_{62 \mathrm{~N}}, 25 \mathrm{E}$ & -13.1 & 11.5 & 26.6 \\
\hline & Helsinki $_{60 \mathrm{~N}}, 24 \mathrm{E}$ & -15.3 & 10.0 & 26.8 \\
\hline \multirow{3}{*}{$\begin{array}{l}\text { Astronomical fall and } \\
\text { winter } 22 \text { Sep-20 Mar } \\
\text { (model \#6) }\end{array}$} & Oulu $_{65 \mathrm{~N}}, 25 \mathrm{E}$ & -35.4 & -4.7 & 15.6 \\
\hline & Jyväskylä $_{62 \mathrm{~N}}, 25 \mathrm{E}$ & -34.1 & -1.4 & 15.2 \\
\hline & Helsinki $_{60 \mathrm{~N}}, 24 \mathrm{E}$ & -36.1 & -3.9 & 14.9 \\
\hline
\end{tabular}

We did not have any socio-economic background variables for the suicide victims. We had the gender and the age of the suicide victims, but the age was not included in the models in order to retain the statistical power. All of the models were constructed in separate for men and women.

In the first model, the Poisson regression with the stepwise model selection was executed with all of the 21 variables, and thereafter, five models with selected variables were constructed (Table 3). For the fifth and sixth models, the study period was split into two parts according to the astronomical seasons in order to analyze suicide rates during the spring-summer seasons and the autumn-winter seasons separately due to the differences in the daylength. The spring and autumn equinoxes were chosen as the cutoff dates. Fifth model included the dates from 21 March to 21 September, with the length of daylight equal or over $12 \mathrm{~h}$ per day. The sixth model included the dates from 22 September to 20 March, with the length of daylight equal or $<12 \mathrm{~h}$ per day. The range in temperature variation during these two aforementioned periods in the three study areas is presented in Table 4.

The statistical program R, version 2.15.0 [23], with the packages Epi [24] and natural spline [25], was used for the statistical analyses. Natural spline method was applied for all of the variables, except numbers $7,8,13,18$, and 19, which were analyzed as categorical variables.

For the interpretation of the chi-square tests, $p$ values of $<0.05$ were considered as significant. In addition, rate ratio was calculated in order to further visualize the results. Rate ratio (RR) compares rate (risk) among one group with the risk among another group (reference group).

\section{Results}

Table 3 shows which explanatory variables were included in the six statistical models that are referred to in the following results. 
Suicide rate in relation to the number of days from the onset of calendar year, calendar year, and weekday

The calendar year from 1974 to 2010 associated with the suicide rates in all of the three study areas (data not shown) in all of the six models, except with the rate of women in Oulu, suggesting a simultaneous general trend in the suicide rates in these three areas. In addition, the suicide rate of men in Helsinki associated with the number of days from the onset of each calendar year in the models 1 and 2, yielding the increased rate ratio in spring and early summer $(p=0.02)$. An association with the day of the week was found for suicide rate of women in Helsinki in the models $1,2,5$, and 6 . Thursdays had the lowest suicide rate by rate ratio of 0.79 (CI $0.68-0.93),(p=0.003)$, compared to Sundays, which were chosen as reference.

Suicide rate in relation to temperature variables

Daily mean temperature associated with the suicide rate of men in Helsinki in the models $4(p=0.01)$, (Suppl.Fig. $\mathrm{S} 1)$, and $6(p=0.002)$, (Suppl.Fig. S2), with the suicide rate of men in Oulu in the model $2(p=0.01)$, (Suppl.Fig. S3), and with the suicide rate of women in Helsinki in the model 6 ( $p=0.04)$, (Suppl.Fig. S4).

The change in daily mean temperature compared to the previous day associated with the suicide rate of men in Jyväskylä in the model 5 ( $p=0.02$ ), (Suppl.Fig. S5).

The change in daily mean temperature compared to the fifth day before the suicides associated with the suicide rate of men in Helsinki in the models 1 and $2, p=0.02$, (Fig. 3), and with the suicide rate of women in Oulu in the models 1,2 , and 4, ( $p=0.02$ ), (Suppl.Fig. S6).

Diurnal temperature change between maximum and minimum daily temperatures associated with the suicide

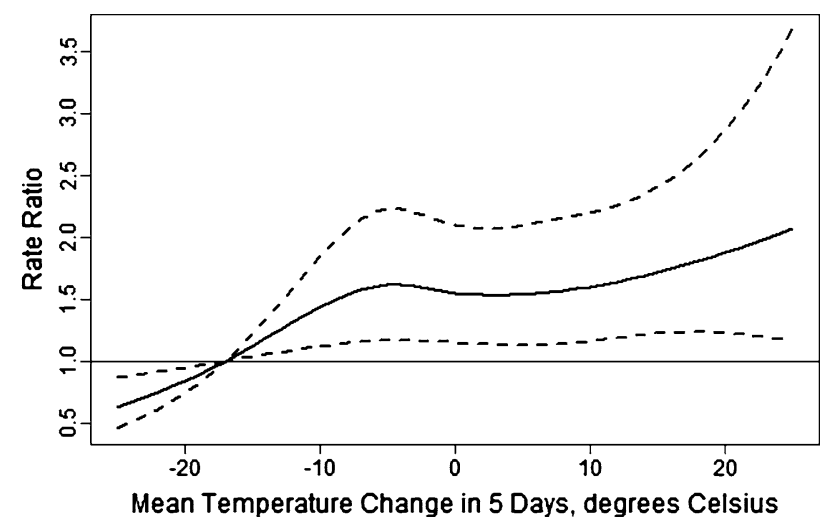

Fig. 3 Rate ratio (solid line), with $95 \%$ confidence intervals (dash lines), for the suicide rate of men in Helsinki in relation to the change in daily mean temperature during 5 days in Helsinki (60N, 24E), from 1974 to 2010 rate of women in Jyväskylä in the model 4 by the rate ratio of 1.024 per each degree of Celsius (CI 1.0-1.05), $(p=0.02)$.

Thermal seasons as categorical variables associated with the suicide rate of women in Jyväskylä in the model 2 $(p=0.02)$ in descending order as follows: spring $(\mathrm{RR}=2.23$, CI 1.6-8.8), winter (reference), autumn $(\mathrm{RR}=0.98, \mathrm{CI} 0.3-3.5)$, and summer $(\mathrm{RR}=0.71, \mathrm{CI}$ 0.7-3.1).

Number of days from the onset of thermal spring associated with the suicide rate of women in Jyväskylä in the model 3 ( $p=0.001$ ), (Fig. 4).

Number of days from the onset of thermal winter associated with the suicide rate of men in Oulu in the models 3 and 4 ( $p=0.02$ ), (Fig. 5).

Suicide rate in relation to astronomical seasons

Variables concerning astronomical seasons associated with suicide rates of men and women only in Jyväskylä, in the model 1. Astronomical seasons used as categorical variables in the model 1 associated with the suicide rate of women in Jyväskylä in following order: summer $(\mathrm{RR}=5.58, \quad \mathrm{CI} \quad 1.5-20.6), \quad$ spring $\quad(\mathrm{RR}=1.37, \quad \mathrm{CI}$ $0.5-3.8)$, winter (reference), and autumn ( $R R=0.63, \mathrm{CI}$ $0.2-2.6)$. The numbers of days from the onsets of astronomical spring $(p=0.002)$ and autumn $(p=0.003)$ associated with suicide rate of women in Jyväskylä. Suicide rate of men in Jyväskylä associated with the number of days from the onset of astronomical summer $(p=0.04)$.

The mismatch time period, that is, the days that overlap between thermal and astronomical seasons, did not associate with suicide rate in any of the study areas.

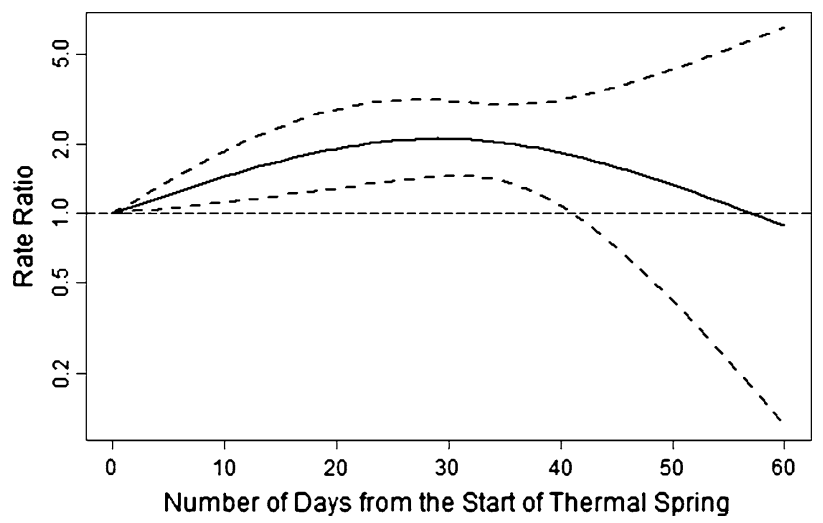

Fig. 4 Rate ratio (solid line), with $95 \%$ confidence intervals (dash lines), for the suicide rate of women in Jyväskylä in relation to the number of days from the onset of thermal spring in Jyväskylä $(62 \mathrm{~N}$, 25E), from 1974 to 2010 


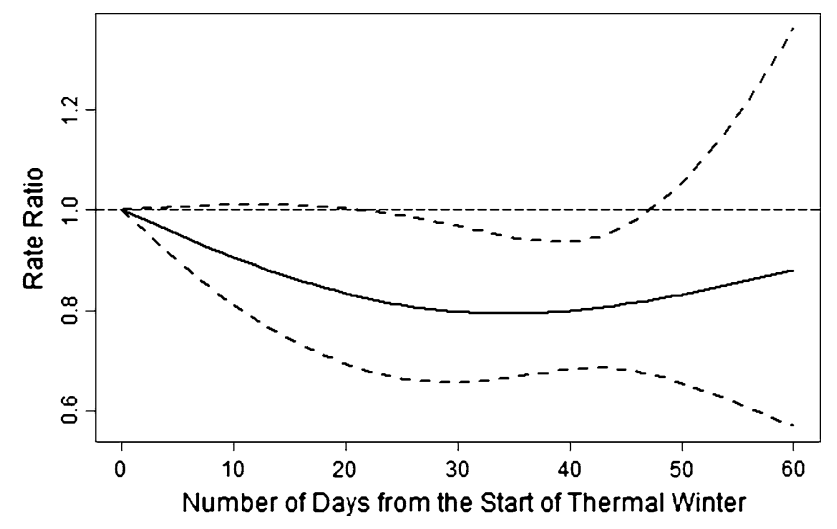

Fig. 5 Rate ratio (solid line) with $95 \%$ confidence intervals (dash lines) for the suicide rate of men in Oulu in relation to the number of days from the onset of thermal winter in Oulu (65N, 25E), from 1974 to 2010

\section{Discussion}

There was diversity in our results, and no single explanatory variable associated uniformly with suicide rates of men and women in the three study areas. Our results seem to suggest that cold temperatures or cooling down may associate with lower suicide rates in Helsinki, and men in Oulu. For women in Oulu, the results are difficult to interpret. In Jyväskylä, the associations seem to be different, if not opposite in direction.

\section{Limitations and strengths}

In evaluating our results, some limitations should be taken into account. First, the main aim of our eco-epidemiologic study was to estimate the association of ambient temperatures with deaths from suicide. Therefore, the $p$ values do not present a formal hypothesis testing, but they are of only a descriptive value and should be considered with caution for interpretation of the results.

Second, although suicide rate in Finland has been among the highest in the world during the study period, with a peak of 38 per 100,000 in 1990, it has decreased down to 15.4 per 100,000 in 2012 . Considering the rather small population of 5.4 million in Finland, the absolute numbers of suicides, especially in women in Jyväskylä and Oulu regions, can, from the statistical point of view, be seen as a limitation (Table 1).

Third, socio-economic factors or data of psychiatric morbidity of the suicide victims were not available. However, these three study areas represent urban settings, with lively universities, implicitly suggesting similarities in the socio-economic structure and psychiatric treatment possibilities.
Fourth, no mediation of weather or interaction of ambient temperature with other weather variables such as humidity or wind speed which all affect to the way we sense temperature could be taken into account. Therefore, our study describes only a narrow segment of weather and its possible association with suicide rate.

The strengths of this study are the daily data of suicides relative to the size of the population for a 37-year-long period, with the local daily weather data, from a country with a relatively high suicide rates. In addition, the suicide statistics may be considered liable and consistent during the study period, due to long and systematical tradition in statistics in general in Finland. In addition, the death from suicide does not carry any legal or religious punishments in Finland.

Suicide rate of men

In the southern coast, in Helsinki region, the rate ratio for men's suicide rate was lower, the lower the daily mean temperature was, both in the year-round analysis (Suppl. Fig. S1) and in the autumn-winter half-year analysis (Suppl. Fig. S2). Furthermore, the smaller the suicide rate of men in Helsinki was, the more robust the decrease in ambient temperature during the preceding 5 days had been (Fig. 3). In contrast to the findings in Helsinki, in the continental part of Finland, in Jyväskylä region, the rate ratio for men's suicide rate slightly decreased the more the daily mean temperature had increased from the previous day (Suppl. Fig. S5). For men, in Oulu region, the rate ratio increases as the daily mean temperature gets higher (Suppl. Fig. S3), and in turn, the rate ratio decreases up till approximately 30 days from the onset of thermal winter when ambient temperature goes below $0^{\circ}$ of Celsius by definition during thermal winter (Fig. 5). The results from Helsinki and Oulu seem to be consistent with the finding of Ajdacic-Gross et al. [9], suggesting that it is the lack of cold that may increase the risk of suicide.

Suicide rate of women

For women in Helsinki region, the rate ratio seems to slightly increase, the higher is the daily mean temperature during the autumn-winter period (Suppl. Fig. S4). For women's suicide rate in Jyväskylä region, three associations were found. First, the rate ratio descends in the following order with the thermal seasons: spring, winter, autumn, and summer. Second, the rate ratio increases up till a duration of approximately 30 days during thermal spring (Fig. 2). Third, the rate ratio increases by 1.024 per degree of Celsius of diurnal change between the daily maximum and minimum temperatures. These results seem to suggest that it maybe the change in temperature that 
increases the suicide risk. This study does not reveal the possible reasons for this, but it can be speculated that vulnerable individuals cannot thermally adapt as quickly as others due to possibly disrupted thermoregulation. In this respect, thermal spring may be more challenging than other thermal seasons, because ambient daily temperatures typically roller coaster between cold at night and warm during the day. A difference between the daily minimum and maximum temperatures may well be of up to $20^{\circ}$ in Celsius (thus, to visualize, generating a rate ratio of up to 20.48) during spring, despite of the fact that the daily mean temperature stays between $0^{\circ}$ and $10^{\circ}$ of Celsius by definition. During thermal summer, autumn, and winter, the diurnal variation in ambient temperature is typically smaller than in spring in Finland.

For women, in Oulu region, the pattern with a slight decrease in rate ratio with a slight decrease in temperature, and a slight increase or rate ratio with a moderate increase in temperature, and further, the "tail" with decrease in rate ratio, while a clear increase in temperature is different from the results of women in Helsinki and Jyväskylä (Suppl. Fig. S6).

\section{Temperature and risk factors for suicides}

In favor of a true association between suicides and ambient temperature are studies showing that psychiatric disorders with elevated suicide risk associate with various thermo regulative abnormalities. It has been shown that the sensation of thermal comfort is influenced by mood and that distressed individuals do not tolerate high temperatures [10]. Furthermore, dysregulation of body temperature has been demonstrated during depressive episodes and in depressive disorder [26, 27] and suspected in schizophrenia [28]. In addition, ambient temperature has associated with hospital admissions due to depressive episodes of bipolar disorder [29] and with those due to schizophrenia [30].

\section{Biological hypotheses}

Although the possible biological explanations for these aforementioned associations are beyond our methods, some suggestions are presented herein. Over-active brown adipose tissue has been found among depressed suicide victims [31], and changes in brain metabolism have been found in people with activated brown adipose tissue [32]. Activated brown adipose tissue appears to produce a hypermetabolic change in the right inferior parietal lobule and a hypometabolic change in the left insula [32]. In depressed adolescents with bipolar disorder, the neural activity in the left insula during emotional processing increases after successful treatment [33], whereas in patients with chronic treatment-resistant depression, the left insula volume is smaller than in healthy controls [34]. Furthermore, peripheral cold receptors in the skin can induce, via the thermoregulatory afferent pathway $[35,36]$, not only heat from brown adipose tissue but also behavioral changes [37]. Exposure to cold, via influence on neurons in the lateral parabrachial nucleus, activates interneurons in the preoptic area to inhibit warm-sensitive inhibitory output neurons and thereby drives thermogenesis [38]. In line with this, thermoregulatory cooling, and the subsequent alleviation of depression, was induced by stimulating peripheral warm-sensitive thermoafferent spinoparabrachial pathway among patients with major depression [39].

We hypothesize herein that it is the increasing thermal stress on warm days after cold nights during spring that may over-activate brown adipose tissue and impair heat tolerance. This impairment is suggested to change neural activity in the brain areas receiving projections from brown adipose tissue [40] and thereby to deepen depression and increase the risk of suicide. Furthermore, reactions along the thermoregulatory afferent pathway seem to depend on phosphatidylinositol 4,5-bisphosphate [41], which is reduced by treatment with lithium [42, 43], which might help in slowing down the over-activated brown adipose tissue. It is of note that neuroleptics may impair thermoregulation $[28,44]$. What comes to the possible differences in thermoregulation between genders, there are several possibilities that may provide an explanation. For instance, the receptor activator of NF-kB ligand (also known as RANKL) and its tumor necrosis factor (TNF) family receptor RANK, which play an essential role in body temperature regulation and are involved in fever mechanisms, seem to interact with ovarian hormones and take part in the physiological temperature regulation in females [45]. If this holds for women and contributes to suicide vulnerability, it is not known.

Concerning genes and gene-environment interactions, there are currently no studies on the possible triggering role of physiologically stressful environmental stimuli, such as weather, in relation to suicidal behavior [46, 47]. However, adrenergic signaling in brown adipose tissue seems to be involved in the regulation of the clock gene expression [48]. Moreover, rapid improvement of depressive mood by total sleep deprivation therapy has been suggested to emerge through the resetting of clock gene functions, leading to correction of the misalignment between the circadian rhythms and sleep [49].

\section{Climatic perspective}

Besides differences in biological vulnerability, a climatic perspective may offer one explanation to the variation in results across the three study areas. Finland is situated between 60 and 70 latitudes, but the climate is not as cold 
as might be expected, and four seasons with warm and light summers and cold and dark winters can be clearly distinguished. However, due to the fact that Finland is over $1100 \mathrm{~km}$ in length in south-north direction, the climatic conditions across Finland vary markedly. In addition, due to the frequently passing high and low pressures, high variability in the daily weather is more typical than in lower latitudes in general. As a consequence, the local climates of these study areas Helsinki, Jyväskylä, and Oulu differ from each other. Helsinki and Oulu are both located by the Baltic Sea, Oulu $600 \mathrm{~km}$ north of Helsinki, and Jyväskylä is in the halfway of Helsinki, and Oulu by southnorth axis, but situated inland, and weather phenomena typical for coastal areas lack from Jyväskylä. Therefore, in our study areas, similar ambient temperature conditions can prevail in different kind of synoptic weather situations with different air humidity, wind speed, and atmospheric pressure, which can be experienced differently from the human point of view. Furthermore, in these areas, the timings of thermal seasons in relation to astronomical seasons and the length of day light differ clearly from each other (Tables 2, 4). Different adaptation mechanisms both psychologically and physiologically are needed in order to acclimatize properly.

\section{Conclusions}

In conclusion, thermal seasons and ambient daily temperature associated with suicide rates suggesting lower suicide rate with lower temperatures, especially among men. Based on our results, the association of ambient temperature with seasonally recurring peaks in suicide rate cannot be ruled out. Further studies are needed to reveal the meaning of our results on individual level. The biological mechanisms, if any, underlying these associations remain to be elucidated in order to find and focus adequate preventive measures to those in need.

Acknowledgments The Finnish National Graduate School for Clinical Investigation allocated scholarships (to $\mathrm{LH}$ ) for this project, but had no further role in the study design.

Conflict of interest The authors declare that they have no conflict of interest.

\section{References}

1. Ruuhela R, Hiltunen L, Venalainen A, Pirinen P, Partonen T. Climate impact on suicide rates in Finland from 1971 to 2003. Int J Biometeorol. 2009;53:167-75.

2. Helama S, Holopainen J, Partonen T. Temperature-associated suicide mortality: contrasting roles of climatic warming and the suicide prevention program in Finland. Environ Health Prev Med. 2013;18:349-55.

3. Holopainen J, Helama S, Partonen T. Does diurnal temperature range influence seasonal suicide mortality? Assessment of daily data of the Helsinki metropolitan area from 1973 to 2010. Int J Biometeorol. 2013 Jun 18, (Epub ahead of print). doi:10.1007/ s00484-013-0689-0.

4. Deisenhammer EA. Weather and suicide: the present state of knowledge on the association of meteorological factors with suicidal behaviour. Acta Psychiatr Scand. 2003;108:402-9.

5. Page LA, Hajat S, Kovats RS. Relationship between daily suicide counts and temperature in England and Wales. Br J Psychiatry. 2007;191:106-12.

6. Ishii N, Terao T, Araki Y, Kohno K, Mizokami Y, Arasaki M, et al. Risk factors for suicide in Japan: a model of predicting suicide in 2008 by risk factors of 2007. J Affect Disord. 2013;147:352-4.

7. Inoue K, Nishimura Y, Fujita Y, Ono Y, Fukunaga T. The relationship between suicide and five climate issues in a large-scale and long-term study in Japan. West Indian Med J. 2012;61:532-7.

8. Dixon PG, McDonald AN, Scheitlin KN, Stapleton JE, Allen JS, Carter WM, et al. Effects of temperature variation on suicide in five U.S. counties, 1991-2001. Int J Biometeorol. 2007;51:395-403.

9. Ajdacic-Gross V, Lauber C, Sansossio R, Bopp M, Eich D, Gostynski M, et al. Seasonal associations between weather conditions and suicide-evidence against a classic hypothesis. Am J Epidemiol. 2007;165:561-9.

10. Yin J, Zheng Y, Wu R, Tan J, Ye D, Wang W. An analysis of influential factors on outdoor thermal comfort in summer. Int $\mathrm{J}$ Biometeorol. 2012;56:941-8.

11. Nayha S. Short and medium-term variations in mortality in Finland. A study on cyclic variations, annual and weekly periods and certain irregular changes in mortality in Finland during period 1868-1972. Scand J Soc Med Suppl. 1981;21:1-101.

12. Hakko H, Rasanen P, Tiihonen J. Seasonal variation in suicide occurrence in Finland. Acta Psychiatr Scand. 1998;98:92-7.

13. Rock D, Greenberg DM, Hallmayer JF. Increasing seasonality of suicide in Australia 1970-1999. Psychiatry Res. 2003;120:43-51.

14. Partonen T, Haukka J, Nevanlinna H, Lonnqvist J. Analysis of the seasonal pattern in suicide. J Affect Disord. 2004;81:133-9.

15. Rocchi MB, Miotto P, Preti A. Seasonal variation in suicides and in deaths by unintentional illicit acute drug intoxications. Addict Biol. 2004;9:255-63.

16. Bridges FS, Yip PS, Yang KC. Seasonal changes in suicide in the United States, 1971 to 2000. Percept Mot Skills. 2005;100:920-4.

17. Zonda T, Bozsonyi K, Veres E. Seasonal fluctuation of suicide in Hungary between 1970-2000. Arch Suicide Res. 2005;9:77-85.

18. Christodoulou C, Douzenis A, Papadopoulos FC, Papadopoulou A, Bouras G, Gournellis R, et al. Suicide and seasonality. Acta Psychiatr Scand. 2012;125:127-46. (Epub 2011 Aug 13.2011).doi:10.1111/j.1600-0447.2011.01750.x.

19. Meares R, Mendelsohn FA, Milgrom-Friedman J. A sex difference in the seasonal variation of suicide rate: a single cycle for men, two cycles for women. Br J Psychiatry. 1981;138:321-5.

20. Nayha S. Autumn incidence of suicides re-examined: data from Finland by sex, age and occupation. $\mathrm{Br} \mathrm{J}$ Psychiatry. 1982;141:512-7.

21. Micciolo R, Zimmermann-Tansella C, Williams P, Tansella M. Seasonal variation in suicide: is there a sex difference? Psychol Med. 1989;19:199-203.

22. Hiltunen L, Suominen K, Lonnqvist J, Partonen T. Relationship between daylength and suicide in Finland. J Circadian Rhythms. 2011;9:10. 
23. R Core Team 2012, R: A language and environment for statistical computing. R Foundation for Statistical Computing, Vienna, Austria. ISBN 3-900051-07-0, http://www.R-project.org/. Accessed 28 Mar 2014.

24. Carstensen B, Plummer M, Laara E, Hills M. 2012. Epi: A Package for Statistical Analysis in Epidemiology, R package version 1.1.49, http://CRAN.R-project.org/package=Epi. Accessed 28 Mar 2014.

25. Hastie TJ. Natural spline, Chap 7 of Statistical Models in S. In: Chambers JM, Hastie TJ, editors. Generalized additive models. Wadsworth \& Brooks/Cole; 1992.

26. Germain A, Kupfer DJ. Circadian rhythm disturbances in depression. Hum Psychopharmacol. 2008;23:571-85.

27. Albrecht U. Circadian clocks in mood-related behaviors. Ann Med. 2010;42:241-51.

28. Chong TW, Castle DJ. Layer upon layer: thermoregulation in schizophrenia. Schizophr Res. 2004;69:149-57.

29. Shapira A, Shiloh R, Potchter O, Hermesh H, Popper M, Weizman A. Admission rates of bipolar depressed patients increase during spring/summer and correlate with maximal environmental temperature. Bipolar Disord. 2004;6:90-3.

30. Sung TI, Chen MJ, Lin CY, Lung SC, Su HJ. Relationship between mean daily ambient temperature range and hospital admissions for schizophrenia: results from a national cohort of psychiatric inpatients. Sci Total Environ. 2011;410-411:41-6.

31. Huttunen P, Kortelainen ML. Long-term alcohol consumption and brown adipose tissue in man. Eur J Appl Physiol Occup Physiol. 1990;60:418-24.

32. Huang YC, Hsu CC, Huang P, Yin TK, Chiu NT, Wang PW, et al. The changes in brain metabolism in people with activated brown adipose tissue: a PET study. Neuroimage. 2011;54:142-7.

33. Diler RS, Ladouceur CD, Segreti A, Almeida JR, Birmaher B, Axelson DA, et al. Neural correlates of treatment response in depressed bipolar adolescents during emotion processing. Brain Imaging Behav. 2013;7:227-35.

34. Serra-Blasco M, Portella MJ, Gomez-Anson B, de Diego-Adelino J, Vives-Gilabert Y, Puigdemont D, et al. Effects of illness duration and treatment resistance on grey matter abnormalities in major depression. Br J Psychiatry. 2013;202:434-40. (Epub Apr 25.2013). doi:10.1192/bjp.bp.112.116228.

35. Bratincsak A, Palkovits M. Evidence that peripheral rather than intracranial thermal signals induce thermoregulation. Neuroscience. 2005;135:525-32.
36. Nakamura K, Morrison SF. A thermosensory pathway that controls body temperature. Nat Neurosci. 2008;11:62-71.

37. Almeida MC, Hew-Butler T, Soriano RN, Rao S, Wang W, Wang $\mathrm{J}$, et al. Pharmacological blockade of the cold receptor TRPM8 attenuates autonomic and behavioral cold defenses and decreases deep body temperature. J Neurosci. 2012;32:2086-99.

38. Morrison SF, Nakamura K, Madden CJ. Central control of thermogenesis in mammals. Exp Physiol. 2008;93:773-97.

39. Hanusch KU, Janssen CH, Billheimer D, Jenkins I, Spurgeon E, Lowry CA, et al. Whole-body hyperthermia for the treatment of major depression: associations with thermoregulatory cooling. Am J Psychiatry. 2013;170:802-4.

40. Vaughan $\mathrm{CH}$, Bartness TJ. Anterograde transneuronal viral tract tracing reveals central sensory circuits from brown fat and sensory denervation alters its thermogenic responses. Am J Physiol Regul Integr Comp Physiol. 2012;302:R1049-58.

41. Fujita F, Uchida K, Takaishi M, Sokabe T, Tominaga M. Ambient temperature affects the temperature threshold for TRPM8 Activation through Interaction of Phosphatidylinositol 4, 5-Bisphosphate. J Neurosci. 2013;33:6154-9.

42. Detera-Wadleigh SD. Lithium-related genetics of bipolar disorder. Ann Med. 2001;33:272-85.

43. Jardín I, Redondo PC, Salido GM, Rosado JA. Phosphatidylinositol 4,5-bisphosphate enhances store-operated calcium entry through hTRPC6 channel in human platelets. Biochimica et Biophysica Acta (BBA)—Molecular. Cell Res. 2008;1783:84-97.

44. Cuddy ML. The effects of drugs on thermoregulation. AACN Clin Issues. 2004;15:238-53.

45. Hanada R, Leibbrandt A, Hanada T, Kitaoka S, Furuyashiki T, Fujihara $\mathrm{H}$, et al. Central control of fever and female body temperature by RANKL/RANK. Nature. 2009;462:505-9.

46. Antypa N, Serretti A, Rujescu D. Serotonergic genes and suicide: a systematic review. Eur Neuropsychopharmacol. 2013;23:1125-42.

47. Mandelli L, Serretti A. Gene environment interaction studies in depression and suicidal behavior: An update. Neurosci Biobehav Rev. 2013; 37:2375-97. (Epub 2013 Jul 22). doi:10.1016/j.neu biorev.2013.07.011.

48. Li S, Yu Q, Wang GX, Lin JD. The biological clock is regulated by adrenergic signaling in brown fat but is dispensable for coldinduced thermogenesis. PLoS ONE. 2013;8:e70109.

49. Bunney BG, Bunney WE. Mechanisms of rapid antidepressant effects of sleep deprivation therapy: clock genes and circadian rhythms. Biol Psychiatry. 2013;73:1164-71. 